日臨外会誌 $65(1), 6-9,2004$

原著

胃原発性 GIST におけるKITレセプター染色の意義

東京女子医科大学消化器病センター外科, 茨城県立中央病院病理*

小田和 理 恵 小熊英俊 喜多村 陽 -

高崎健 板 橋 正 幸*

【目的】胃原発広義 GIST の手術適応における KIT レセプターの臨床的意義を検討し た.【対象】1987年〜2001年に切除した胃原発広義 GIST75例.【方法】LSAB 法にて $\alpha$ SMA，s-100蛋白，KITレセプターの免疫染色を行った。【結果】1 Rosai 分類いずれの 群にも悪性例を認めた。 (2)腫場径 $4 \mathrm{~cm}$ 末満の症例に約 $40 \%$ の悪性例を含む. (3)全症例の $76 \%$ K゙ KITレセプター陽性. (4) KITレセプタ一陰性例に悪性例なく，陽性例中 $63 \%$ \%゙ 悪性例. (5)再発 8 例全例に KIT レセプター陽性.【結論】広義の胃 GIST は腫陽径で手 術適応を判断してきたが, KIT レセプター陰性症例に悪性例を認めない結果より生㭘可 能であれば KIT レセプター染色性により手術適応を判断でき,特に腫場径の小さい粘膜 下腫韵の手術適応の判断に有用である。

索引用語：GIST, KITレセプター, c-kit, 悪性度

\section{緒言}

従来, 組織学的に平滑筋腫あるいは平滑筋肉腫と考 えられてきた胃粘膜下腫場の多くは現在 gastrointestinal stromal tumor (GIST) と考えられるようにな ってきた. Rosai' の分化の有無により 4 種に分類し，いずれの細胞への 分化も示さないものを狭義の GIST，狭義のGISTに 対して 4 種全てを広義の GIST とし，その細胞起源を 推定した。近年, Hirota ら ${ }^{2 / 31}$ は多くの広義の GIST は KIT レセプターゃCD34を発現することからその腫場 起源が消化管渾動のペースメーカー練胞である Cajal の介在細胞（ICCs）であると推察している4.さらら， Hirota らは広義の GISTには高頻度にc-kit 遦伝子 の変異があることを明らかにした. c-kit 遺伝子の変 異およびその産物であるKITレセプターはGISTの 発生起源を推祭することに重要なだけでなく，その自 律的活性化が腫惶の増殖と関係することから臨床的に きわかて重要と考えられる，さらに最近，KITレセフ ターの tyrosinkinase 部分を選択的に阻害する薬郕 STI571が開発されるに至り，胃粘膜下腫激における

2003年6月25日受付 2003年11月 4 日採用 〈所属施設住所〉

T162-8666 東京都新宿区河田町 8-1
KITレセプターの発現の検索はますます臨床的に重 要となる可能性を秘めているす)。そこで,これまでの胃 粘膜下腫湯として切除した症例における KITレセプ ターの発現からその臨床的な意義について検討した。 研究対象および方法

1987年 1月〜2001年12月までの15年間に当科で胃粘 膜下腫場の䛦断で切除し，HE染色にて広義の GIST と診断した75例を対象とした。

全例10\%ホルマリン浴液にて固定，腫湯中心を含む 切片をパラフィン包理後 $2 \mu \mathrm{m}$ の厚さに薄切し, Hematoxylin・Eosin染色および $\alpha$-smooth muscle $\operatorname{actin}(\alpha-\mathrm{SMA}$ ：マウスモ)クローナル抗体, DAKO 社)，S-100蛋白(ウサギポリクローナル抗体，DAKO 社), CD34 (マウスモノクローナル抗体, DAKO 社), c-kit（ウサギポリクローナル抗体，DAKO 社）を使用 しLSAB 法による免疫染色を行った。

腫漡の組織学的良・熹性診断は Ueyama $5^{6)}$ の診断 基準を参考に,400倍30視野において核分裂数 0 個を良 性とし 3 個以上を悪性とした．核分裂数 $1 \sim 2$ 個につ いては細胞密度が高いもの，または核異型度が中〜高 度示すものについて悪性と判断した。

\section{1. 広義の GIST の分類}

成 續

Rosai の分類に従い， $\alpha$-SMA と S-100蛋白の免疫 
表 1 広義のGISTの細分類(Rosai分類)

\begin{tabular}{lrr}
\hline \multicolumn{1}{c}{ 細分類 } & 症例数 & \multicolumn{1}{c}{ 頻度 } \\
\hline Smooth muscle type(S型) & 28 例 & $37.3 \%$ \\
Neural type(N型) & 7 例 & $9.4 \%$ \\
Combined smooth muscle-neural type(C型) & 3 例 & $4.0 \%$ \\
Uncommitted type(U型) (狭義のGIST) & 37 例 & $49.3 \%$ \\
\hline \multicolumn{1}{c}{ 計 } & 75 例 & $100 \%$ \\
\hline
\end{tabular}

S型： $\alpha$-SMA(+) $-100(-) \quad$ N型： $\alpha$-SMA $(-) \mathrm{s}-100(+)$ C型： $\alpha-\operatorname{SMA}(+) \mathrm{s}-100(+)$ U型： $\alpha-\operatorname{SMA}(-) \mathrm{s}-100(-)$

表 2 胃GIST，Rosai分類別良悪性頻度

\begin{tabular}{crrr}
\hline 料分類 & \multicolumn{1}{c}{ 良性 } & \multicolumn{1}{c}{ 㦞性 } & \multicolumn{1}{c}{ 計 } \\
\hline $\mathrm{S}$ 型 & 18 例 $(64.3 \%)$ & 10 例 $(35.7 \%)$ & 28 例 $(100 \%)$ \\
$\mathrm{N}$ 型 & 6 例 $(85.7 \%)$ & 1 例 $(14.3 \%)$ & 7 例 $(100 \%)$ \\
$\mathrm{C}$ 型 & 2 例 $(66.7 \%)$ & 1 例 $(33.3 \%)$ & 3 例 $(100 \%)$ \\
$\mathrm{U}$ 型 & 13 例 $(35.1 \%)$ & 24 例 $(64.9 \%)$ & 37 例 $\left(100^{\circ} \%\right)$ \\
\hline 計 & 39 例 $(52.0 \%)$ & 36 例 $(48.0 \%)$ & 75 例 $(100 \%)$ \\
\hline
\end{tabular}

表 3 胃GISTの最大腫㿋径別量恶性頻度

\begin{tabular}{crcc}
\hline 最大腫鹤径 & 良性 & 墨性 & 計 \\
\hline $4 \mathrm{~cm}$ 未満 & 17 例 $(60.7 \%)$ & 11 例 $(39.3 \%)$ & 28 例 $(100 \%)$ \\
$4 \mathrm{~cm} \sim 8 \mathrm{~cm}$ & 21 例 $(58.3 \%)$ & 15 例 $(41.7 \%)$ & 36 例 $(100 \%)$ \\
$8 \mathrm{~cm}$ 上 & 1 例 $(9.1 \%)$ & 10 例 $(90.9 \%)$ & 11 例 $(100 \%)$ \\
\hline 計 & 39 例 $(52.0 \%)$ & 36 例 $(48.0 \%)$ & 75 例 $(100 \%)$ \\
\hline
\end{tabular}

染色の結果加ら75例の胃原発広義の GIST は(1) smooth muscle type (S 型) 21例, (2) neural type (N 型) 7 例, (3) combined smooth muscle-neural type (C 型) 3 例, (4) uncommitted type (U 型) 37例に分 類された（表 1 ).

\section{2 . 組織学的悪性例}

前述の基準に従うと良性39例(52.0\%), 悪性36例(48 \%)に分類された。

\section{3. 広義の GIST の分類と悪性例の頻度}

$\mathrm{S}$ 型 $\mathrm{N}$ 型 $\mathrm{C}$ 型 $\mathrm{U}$ 型のいずれの分類にも頻度は異な るものの悪性例を認めた（表 2 ）。

\section{4. 最大腫痗径別悪性頻度}

最大腫場径では最小 $2.2 \mathrm{~cm}$ から瑟性例を認め, 最大 は $30.0 \mathrm{~cm}$ であった. 最大腫場径を $4.0 \mathrm{~cm}$ 末満, $4.0 \mathrm{~cm}$ 以上 $8.0 \mathrm{~cm}$ 末満， $8.0 \mathrm{~cm}$ 以上の 3 群に分類し，検討寸 ると $8.0 \mathrm{~cm}$ 以上の症例はその他の 2 群と比較し有意 に悪性例の頻度が高かった（表 3 ）。

5. 広義の GIST の分類別 KIT レセプター陽性頻度
表 4 胃GISTのRosai分類別KITレセプター陽性頻度

\begin{tabular}{crrr}
\hline 勫分類 & KIT陰性 & \multicolumn{1}{c}{ KIT陽性 } & \multicolumn{1}{c}{ 計 } \\
\hline $\mathrm{S}$ 型 & 9 例 $(32.1 \%)$ & 19 例 $(67.9 \%)$ & 28 例 $(100 \%)$ \\
$\mathrm{N}$ 型 & 6 例 $(85.7 \%)$ & 1 例 $(14.3 \%)$ & 7 例(100\%) \\
$\mathrm{C}$ 型 & 2 例 $(66.7 \%)$ & 1 例 $(33.3 \%)$ & 3 例 $(100 \%)$ \\
$\mathrm{U}$ 型 & 1 例 $(2.7 \%)$ & 36 例 $(97.3 \%)$ & 27 例 $(100 \%)$ \\
\hline 棓 & 18 例 $(24.0 \%)$ & 57 例 $(76.0 \%)$ & 75 例 $(100 \%)$ \\
\hline
\end{tabular}

表 5 広義GISTにおけるKITレセプターとCD34の発現

\begin{tabular}{rrr}
\hline & KIT陽性 & \multicolumn{1}{c}{ KIT陰性 } \\
\hline CD34陽性 & 57 例 $(76 \%)$ & 3 例 $(4 \%)$ \\
CD34陰性 & 0 例 $(0 \%)$ & 15 例 $(20 \%)$ \\
\hline
\end{tabular}

表 6 胃GISTのKITレセプター染色性と良悪性頻度

\begin{tabular}{llll}
\hline KIT染色性 & \multicolumn{1}{c}{ 良性 } & \multicolumn{1}{c}{ 悪性 } & \multicolumn{1}{c}{ 計 } \\
\hline KIT陰性 & 18 例 $\left(100^{\circ} \%\right)$ & 0 例 $(0 \%)$ & 18 例 $(100 \%)$ \\
KIT陽性 & 21 例 $(36.8 \%)$ & 36 例 $(63.2 \%)$ & 57 例 $(100 \%)$ \\
\hline 計 & 39 例 $(52.0 \%)$ & 36 例 $(48.0 \%)$ & 75 例 $(100 \%)$ \\
\hline
\end{tabular}

いずれの群にも KIT レセプタ一陽性例を認めた、N 型群，C 型群はそれぞれ1例のみ陽性であり，U 型群 は1例をのぞき KITレセプター陽性であった(表 4 )。 6.広義の GIST における KIT レセプターと CD 34の 発現

広義の GIST は KIT レセプター(+), CD34(+)， 57例, KITレセプター(+), CD34(-) 0 例, KITレセ プター(-) CD34(+) 3 例, KITレセプター(-) $\mathrm{CD} 34(-) 15$ 例に分類された（表 5 )。

\section{KIT レセプター, CD 34の発現と悪性列頻度}

KITレセプター陰性例あるいはCD34陰性例いずれ にも悪性例を認好ず, KITレセプター陽性57例のうち 36例（63.2\%）が悪性例であった（表 6 )。

\section{8 . 臨床的悪性例}

絶対的悪性例である臨床的悪性例，すなわち治瘾切 除後の再発 $x$ 例の詳細を表 7 に提示した. 最大腫䄈径 では $5.0 \mathrm{~cm} \sim 30.0 \mathrm{~cm}$ に分布し，平均は $14.8 \mathrm{~cm}$ であっ た。核分裂数は 8〜66に分布し平均 25.8 であった。細 胞密度は全例が高密度で核異型は高度核異型例が多か った. 広義の GIST の分類では N 型には再発例を認め なかった，再度形式は肝転移が全例に認められ，腹膜 転移再発を合併した症例が 3 例に認められた。 
表 7 絶対的悪性例 (再発 8 例)

\begin{tabular}{|c|c|c|c|c|c|c|c|c|}
\hline & 臑湟径 & 核分裂数 & 細胞密度 & 核潩型度 & $\mathrm{KIT}$ & CD34 & 分類 & 再発形式 \\
\hline 1. & $5.0 \mathrm{~cm}$ & 12 & 高 & 高 & 強陽性 & 強陽性 & U型 & 肝転移 \\
\hline 2. & $25.0 \mathrm{~cm}$ & 34 & 高 & 高 & 強陽性 & 強陽性 & $\mathrm{U}$ 型 & 肝転移 \\
\hline 3. & $8.0 \mathrm{~cm}$ & 14 & 高 & 高 & 強陽性 & 強陽性 & $\mathrm{U}$ 型 & 肝転移 \\
\hline 4. & $30.0 \mathrm{~cm}$ & 30 & 高 & 高 & 強陽性 & 強陽性 & C型 & 肝軾移+腹膜転移 \\
\hline 5. & $22.0 \mathrm{~cm}$ & 22 & 高 & 高 & 弱陽性 & 强陽性 & U一型 & 肝転移十腹膜転移 \\
\hline 6. & $10.5 \mathrm{~cm}$ & 20 & 高 & 中 & 強陽性 & 弱陽性 & U 型 & 肝転移十腹膜転移 \\
\hline$\tau$. & $16.0 \mathrm{~cm}$ & 8 & 高 & 高 & 強腸性 & 强陽性 & S型 & 肝転移 \\
\hline 8. & $7.2 \mathrm{~cm}$ & 66 & 高 & 中 & 強陽性 & 強院性 & U型 & 肝転移 \\
\hline
\end{tabular}

\section{考 察}

従来の $\mathrm{H} ・ \mathrm{E}$ 染色や鍍銀染色にて筋原性腫湯あるい は神経原性腫汮とされてきた消化管問葉系腫瘍は近 年，広義の GIST という包括した概念として捉えられ るようになってきた．臨床的には胃における粘膜下腫 瘍として遭遇することが少なくないが，その良悪性の 鑑別が困難なことから，その手術適応に関しては以前 から議論が多いところである．GISTの概念はその腫 愓起源を考える上で新しい考え方ではあるが，臨床的 な取り扱いを考光る上では従来の筋原性腫富の考光方 を変えるまでには至らなかった、したがって,GISTに 対してもその大きさや增大傾向により悪性度を推定 し，手術適応を決定せざるを得ないのが現状である。 一方, 罢原発要性 GIST の治療成績は最大腫場径が小 さい症例ほど良好であり，当科の治療成績でも最大腫 瘍径 $4 \mathrm{~cm}$ 末満の症例に再発を認めていない7. 近年, 内視鏡検查の進歩により，より小さな胃粘謿下腫瘍が 指摘されることが多いと思われるが，経過観察の上增 大傾向が認められた場合, 腄嚗最大径 $4.0 \mathrm{~cm}$ 末満て切 除するためにはどの程度の期間で経過観察する必要が あるかの結論はなく、より小さな粘膜下腫崵の臨床的， 客観的な良悪性判断の指標が求められている。1998年 Hirota ら ${ }^{21}$ は， c-kit 遺伝子の産物 KIT レセプターが 多くの GIST で発現することと c-kit 遺伝子に機能獲 得性突然变異が存在することを報告した。この報告は 同様に GISTにおいて発現することの多いCD34とと もに消化管における多くの GIST の起源が消化管運 動のペースメーカー細胞として知られるCajal の介在 細胞 (ICCs) であると推定される根拠となっている. KITレセプターおよびCD34がともに陽性である GISTがこの細胞起源であるとすれば，今回検討の75 例のうち57例，76\%が ICCs 起源と考えられる。

また, KITレセプターは組織学的な GIST の起源を
推定するだけでなく，增殖にも関与していることが推 測されている. c-kit 遺伝子の機能獲得性突然変異か ら発現した異常KITレセプターは，細胞内の tyrosinkinase 部分が自律的活性化する構造になりこれが腫 㳻性增殖に深く関与している。したがって KITレセフ ターの tyrosinkinase 活性を抑えることができれば理 論的にはGISTの増殖を抑えることが可能とな $る^{518)}$. 実際2001年, Joensun ら ら $^{9}$ は根治切除不能の再発 GISTに対しKITレセプターの tyrosinkinase 阻害 粫であるSTI571を使用し，著効した症例を報告して いる。これまで有効な化学療法のなかった GISTにお いて画期的な報告であった。

以上の上うに胃粘膜下腫湯の大部分を占める広義の GISTにおいて，KITレセプターの発現はその腫場起 源を推定するだけでなくその悪性度，加えて治療に関 して重要な意味を持つ可能性を秘めている。

広義の GIST の組織学的な悪性度についての報告 は少ないが，同様に扱える平滑筋肉腫に関する論文は 少なくない，しかし，核分裂数，細胞密度，核異型度， 腫湟径などをその基準とすることが多いものの一致し た見解は得られていない，今回の検討において KITレ セプター陰性例に組織学的悪性例がなかったことは GIST を臨床的に取り扱う場合に重要な意味を持つ。 胃粘膜下腫煌に遭遇した場合，その腫瘍がGISTであ るという診断は可能であるが特に腫瘍径が小さな場 合，臨床的な良悪性の診断が不可能であるため手術適 応がこれまで定められなかった。また，臨床的良悪性 䛦断のためにEUS下における腫瘍穿刺細胞診を行う こともこれまで若干の報告はあるが，腫瘍細胞の採取 はできるものの採取量が少ないためその良悪性の猃断 は困難とされてきた。しかし，KITレセプターは腫湯 内にびまん性に発現することから採取量が少なくても KITレセプター発現の有無を確認できる可能性が高 
く，今後腄瑝径の小さい粘膜下腫瘍における穿刺細胞 診の KITレセプター発現は手術適応の1つの指標と なり得ると考えられた。

$$
\text { 結語 }
$$

胃原発広義GIST75例についてKITレセブター染 色性と良悪性について検討した。その結果広義 GIST は KIT レセブター陰性18例, 陽性57例に分類され，陰 性例には悪性例を認めなかったこのことから KITレ セプターの有無が今後手術適応判断における一つの重 要因子となり得ると考えられた。

\section{文献}

1) Rosai J : Ackerman's Surgical Pathology. $8^{\text {th }}$ Ed., Mosby-Year Book, Inc.. St Louis. Chicago, 1996, p645-647, p691-693

2) Hirota $S$, Isozaki $K$, Moriyama $Y$, et al : Gainof-function mutations of $c^{-}$kit in human gastrointestinal stromal tumors. Science $279: 577$ $-580,1998$

3) Hirota $S$, Nishida $T$, Isozaki $K$, et al : Gain-offunction mutation at the extracellular domain of KIT in gastrointestinal stromal tumors. J Pathol 193:505-510. 2001
4) Lars-Gunnar $K$, Helen ER, Frank A : Gastrointestinal pacemaker cell tumor (GIPACT) gastrointestinal stromal tumors show phenotypic characteristics of the interstitial cells of Cajal. Am J Pathol $152: 1259-1269$, 1998

5）西田俊朗：消化管間質細胞腫の診断と治療。細胞 $34: 158-161,2002$

6) Ueyama $T, \mathrm{Ke}-J i a n \mathrm{G}$, Hashimoto $\mathrm{H}$, et al : A clinicopathologic and immunohistochemical study of gastrointestinal stromal tumors. Cancer $69: 947-955,1992$

7）遠藤昭彦, 小熊英俊, 笹川 剛他：広義の胃腸間 葉系腫第細分類の臨床的意義とその治療。東京女 医大誌 $71: 1-6,2001$

8）大橋明子, 廣田誠一: 消化管間質細胞瑀の病理. 細胞 34:154-157, 2002

9) Joensuu H, Roberts PJ. Sarlomo-Rikala M. et al:Effect of the tyrosine kinase inhibitor STI571 in a patient with a metastatic gastrointestinal stromal tumors. N Engl J Med 344: 1052-1056, 2001

\title{
THE CLINICAL VALUE OF THE KIT RECEPTOR IN GASTROINTESTINAL STROMAL TUMORS OF THE STOMACH
}

\author{
Rie OTAWA, Hidetoshi OGUMA, Yoichi KITAMURA, \\ Ken TAKASAKI and Masayuki ITABASHI* \\ Department of Surgery. Tokyo Women's Medical University Hospital \\ *Pathology Division of lbaraki Prefectural Central Hospital
}

We examined the surgical indication for gastrointestinal stromal tumors of the stomach (GIST) in a total of 75 patients who underwent surgery for GIST at the hospital from 1987 to 2001. Malignant tumors were seen in every tpye of Rosai's classification, and in $40 \%$ of cases with a tumor size under $4 \mathrm{~cm}$ in diameter. Seventy-six percent of all cases were positive for KIT receptor. No malignant tumors were found in cases negative for KIT receptor while $63 \%$ of positive cases were malignant tumors. All recurrent cases showed positive reaction to KIT receptor. The surgical indication for GIST of the stomach has been determined on the basis of tumor size. However, this study resulted in that there were no malignant tumors among cases negative for KIT receptor. It is consequently useful to perform preoperative biopsy for gastric GIST, especially for small submucosal tumors, to evaluate the surgical indication on the basis of the immunohistochemical findings of the KIT receptor. 